\title{
Morphological and Genetic Characterization of Saimiri boliviensis
}

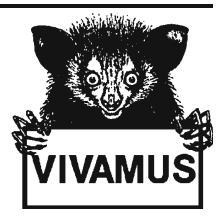

\author{
Eliana Ruth Steinberg • Mariela Nieves • \\ Marina Sofía Ascunce • Ana María Palermo • \\ Marta Dolores Mudry
}

Received: 6 April 2008/Accepted: 29 June 2008/

Published online: 20 January 2009

(C) Springer Science + Business Media, LLC 2009

\begin{abstract}
The taxonomy of Saimiri is controversial because morphological characteristics, traditionally used for identification, are insufficient to distinguish species and subspecies. Genetic studies of specimens become relevant for captive management, especially considering their frequently unknown geographical origin. We analyzed phenotypic and genetic parameters in Saimiri spp. in Argentinean zoological gardens and biological stations to provide a more accurate taxonomic identification. We studied 27 males and 19 females of Saimiri spp. The cytogenetic analysis in mitotic metaphases corroborated a modal number of $2 \mathrm{~N}=44, \mathrm{XX} / \mathrm{XY}$, and $\mathrm{FN}=75$ for males and $\mathrm{FN}=76$ for females. G- and C-bands, fluorescence in situ hybridization (FISH) and the pelage coloration pattern of all the specimens corresponded to Saimiri boliviensis boliviensis. We characterized for the first time the sperm cell morphology and morphometry (mean $\pm \mathrm{SE}$ ): total length: $71.39 \pm$ $5.40 \mu \mathrm{m}$; head length: $5.71 \pm 0.81 \mu \mathrm{m}$; head width: $3.76 \pm 0.70 \mu \mathrm{m}$; acrosome length: $3.70 \pm 0.82 \mu \mathrm{m}$; midpiece length: $12.20 \pm 2.22 \mu \mathrm{m}$. Researchers can use the characterization of the sperm morphology as another parameter for taxonomic identification that, together with cytogenetic and molecular ones, would allow a more precise identification of individual Saimiri boliviensis boliviensis.
\end{abstract}

Keywords $C O I I \cdot$ cytogenetics $\cdot$ Saimiri $\cdot$ sperm morphology

E. R. Steinberg $(\bowtie) \cdot M$. Nieves $\cdot$ M. S. Ascunce $\cdot$ M. D. Mudry

Grupo de Investigación en Biología Evolutiva (GIBE). FCEyN, UBA. CONICET. Laboratorio 46,

4to. Piso, Pabellón II, Ciudad Universitaria, Intendente Güiraldes 2160 (C1428EHA),

Buenos Aires, Argentina

e-mail: steinberg@ege.fcen.uba.ar

M. S. Ascunce

USDA-ARS Center for Medical, Agricultural and Veterinary Entomology,

1600 SW 23rd Drive, Gainesville, FL 32608, USA

A. M. Palermo

CITEFA. Juan Bautista de la Salle 4397 (B1603ALO), Buenos Aires, Argentina 


\section{Introduction}

The primary habitat of Saimiri spp. is the rain forest along the Amazon River with the south marginal distribution in the north of Bolivia and the north marginal distribution in the Guyanas (Hershkovitz 1984). In a revision of the genus considering morphological, karyotypic, behavioral, and biogeographical traits, Hershkovitz (1984) proposed 4 species: Saimiri oerstedii, S. sciureus, S. ustus, and S. boliviensis.Other researchers considered only 2 species based on the same traits: Saimiri sciureus and S. oerstedii (Costello et al. 1993). Further, a cladistic analysis of the genus based on sequence data of the mitochondrial control region together with behavioral and morphological data (Boinski and Cropp 1999) supported the taxonomic proposal of Hershkovitz (1984) considering 4 species: Saimiri oerstedii, S. sciureus, S. ustus, and S. boliviensis. Rowe (1996), Rylands et al. (2000), and Groves (2001) concurred with Hershkovitz's taxonomy of 4 species: Saimiri sciureus, S. boliviensis, S. ustus, S. oerstedii, but categorize as a species $S$. vanzolinii, first described by Ayres (1985). The uncertainty in the systematics of the genus created problems in establishing colonies because the inaccurate taxonomic identification of the individuals and the lack of information about their geographic origin led to the integration of mixed groups (Fogle 1990).

The pelage coloration pattern, traditionally used for taxonomy, is insufficient for a proper characterization of individuals (Fogle 1990). Consequently, hybrids of Saimiri form groups in captivity that are not useful for the development of conservation plans because they do not represent natural populations (Schreiber et al. 1998). Thus, it is important to study as many traits as possible for the identification of subjects to establish a useful classification for those that require taxonomic certainty.

In this framework, the genetic characterization of specimens in captivity for exhibition or recovery and later donation to specialized centers is of great significance (Nieves et al. 2003; Szapkievich et al. 2002; VandeBerg et al. 1990). Among genetic tools, cytogenetic characterization is very useful for taxonomic determination (Moore et al. 1990; Mudry et al. 1995).

The different species of Saimiri share a chromosome number of $2 \mathrm{~N}=44, \mathrm{XX} / \mathrm{XY}$. However, the number of chromosome arms (fundamental number, FN) of their karyotypes is different owing to pericentric inversions, which in turn will originate heterocygotic hybrids that may undergo a reduction in fertility (Moore et al. 1990).

We aimed to add new genetic parameters as tools for an accurate taxonomic identification of the individuals together with an estimation of genetic diversity in squirrel monkey colonies as a complement of the morphological traits traditionally used for classification.

\section{Materials and Methods}

The Primates Project (GIBE, University of Buenos Aires) has studied 46 specimens of both sexes of Saimiri sp. All of them, 27 males and 19 females, were in the following breeding or exhibition centers: 6 females and 18 males from Estación Biológica Corrientes (EBCo, ex-CAPRIM; San Cayetano, Corrientes Province), 6 
males from Complejo Ecológico Municipal (Roque Saenz Peña, Chaco Province), 7 females from Buenos Aires Zoological Garden (Buenos Aires city), 1 female from Cordoba Zoological Garden (Córdoba, Córdoba Province), and 5 females and 3 males from La Plata Zoological Garden (La Plata, Buenos Aires Province). We reevaluated published data of our group (García et al. 1995; Mudry de Pargament et al. 1982; Mudry et al. 1990; Szapkievich et al. 2002) and studied 8 new specimens: the female from Cordoba Zoological Garden and 4 males and 3 females from EBCo. All specimens from EBCo originated from a colony started with individuals from Santa Cruz de la Sierra, Bolivia. The ultimate origin of the specimens from Complejo Ecologico Municipal and from the Zoos of Buenos Aires, Córdoba and La Plata was unknown.

\section{Phenotypic Identification}

The taxonomic classification of each specimen followed the species-specific pelage coloration patterns described by Herskovitz (1984). We simultaneously recorded the body mass via a $20-\mathrm{kg}$ veterinary scale.

\section{Spermatozoan Morphology}

Samples We obtained smears from testicular biopsies performed under anesthesia (Zelazol, Fort Dodge) in 2 captive males at the EBCo. They are descendants of a colony started in 1975 with specimens from Santa Cruz de la Sierra, Bolivia, within the natural distribution of Saimiri boliviensis boliviensis. The genus undergoes a seasonal acquisition and loss of body fat — fatted state - associated with seasonal spermatogenesis cycles (Du Mond 1967). Because the EBCo is located at the south of the natural distribution of Saimiri boliviensis, we verified the occurrence of the mating season. Accordingly, we recorded the annual change in body mass, thus corroborating the fatted male phenomenon on every male analyzed during June, July, and August (data not shown). We performed sperm cell studies during the peak of fatting. We karyotyped both specimens to confirm the assignment to Saimiri boliviensis boliviensis.

Laboratory methods We stained the slides via the Howell and Black (1980) technique, which is specific for sperm cells. To characterize sperm morphology, we recorded data via an optical Leica DMLB microscope at $630 \times$, analyzing $\geq 100$ spermatozoa per individual. We performed the measurements of total length, midpiece length, acrosome length, head length, and head width via a $\times 10$ graduated ocular lens with $0.95 \mu \mathrm{m}$ as resolution limit. We also studied the sperm cells via a 2010 ElectroScan Environmental Scanning Electron Microscope (ESEM) to set up the new procedure for the morphological characterization of reproductive cells in primates. The ESEM allowed the observation and the measurement of cells in the smears at higher magnifications without any previous treatments, with a higher degree of accuracy and precision. We analyzed smears from the same 2 specimens in aluminum plates especially designed for ESEM. We compared the ESEM measurements with the ones obtained via optical microscopy via a $\chi^{2}$ test (statistical analysis tools, Microsoft Excel 2000). To describe sperm 
head morphology, we used the aspect ratio (total head length/width at the midpoint) (Meisner et al. 2005).

\section{Cytogenetic Studies}

Samples We collected peripheral blood samples from all specimens via femoral vein puncture with disposable syringes using heparin (Abott) as an anticoagulant.

Laboratory methods We prepared lymphocyte cell cultures over $72 \mathrm{~h}$ following standard methods (Buckton and Evans 1973, modified). We stained metaphases via G-banding, C-banding, and sequential G/C-banding (Seabright 1971, modified as in Steinberg et al. 2007; Sumner 1972). We arranged the metaphases following the pattern in García et al. (1995). We performed fluorescence in situ hybridization (FISH) with the X and Y human chromosome probes following Nieves et al. (2005) to verify their presence in the mitotic karyotype of Saimiri boliviensis.

\section{Mitochondrial Nucleotide Variability}

Samples We analyzed the nucleotide sequence variation in Saimiri boliviensis boliviensis at the mitochondrial cytochrome $c$ oxidase subunit II (COII) gene to help in the taxonomic determination of the specimens. We analyzed 2 blood samples of Saimiri sp. and obtained the mitochondrial COII sequences previously reported by Ascunce et al. (2002, 2003). The Complejo Ecológico Municipal R. S. Peña identified 1 specimen of Saimiri as Saimiri boliviensis boliviensis, though its geographic source is unknown (GenBank accession no. AF396460). The second specimen of Saimiri, a captive at EBCo, was identified as Saimiri boliviensis boliviensis (GenBank accession no. AF181090), from Santa Cruz de la Sierra, Bolivia. We karyotyped both specimens to confirm the assignment to Saimiri boliviensis boliviensis.

Laboratory methods and data analysis We followed standard protocols of DNA extraction via blood samples (Walsh et al. 1991). We amplified the complete COII sequence via the polymerase chain reaction (PCR) with primers L7552 and H8321 (Ruvolo et al. 1991). We manually sequenced the purified PCR products. We estimated P-nucleotide distances via Mega v 2 (Kumar et al. 2001). A detailed description of the laboratory methods is in Ascunce et al. $(2002,2003)$.

\section{Results}

Phenotype and Sperm Morphology

We identified adult specimens of both sexes via phenotypic characteristics according to species-specific pelage coloration patterns of Saimiri boliviensis boliviensis 
(Hershkovitz, 1984): grayish agouti forehead to entirely black crown, with whitish band absent; nearly bare or thinly haired, agouti or whitish superciliary region; inconspicuous supraorbital vibrissae; comparatively thin blackish tail pencil. There is a dominantly or entirely blackish crown and preauricular patch in males and females; grayish or buffy agouti to blackish upper surface of tail except for the blackish terminal portion. We followed Hershkovitz's classification considering that it is the one more strongly supported by morphological and genetic evidence.

The average body mass during the reproductive season is $914.58 \pm 13.78 \mathrm{~g}$ for male and $752.5 \pm 74.6 \mathrm{~g}$ for female specimens. Sperm morphology in males identified as Saimiri boliviensis boliviensis via phenotypic and cytogenetic analysis presented an oval-rounded head in the frontal view that appears ensiform in the lateral view. As in most of eutherian mammals, the insertion of the tail is central (Fig. 1a and b). We obtained total, midpiece, acrosome, head length, and head width measurements via optical microscopy in 100 sperm cells/individual from 2 specimens. There is no statistical difference between them, evaluated via a
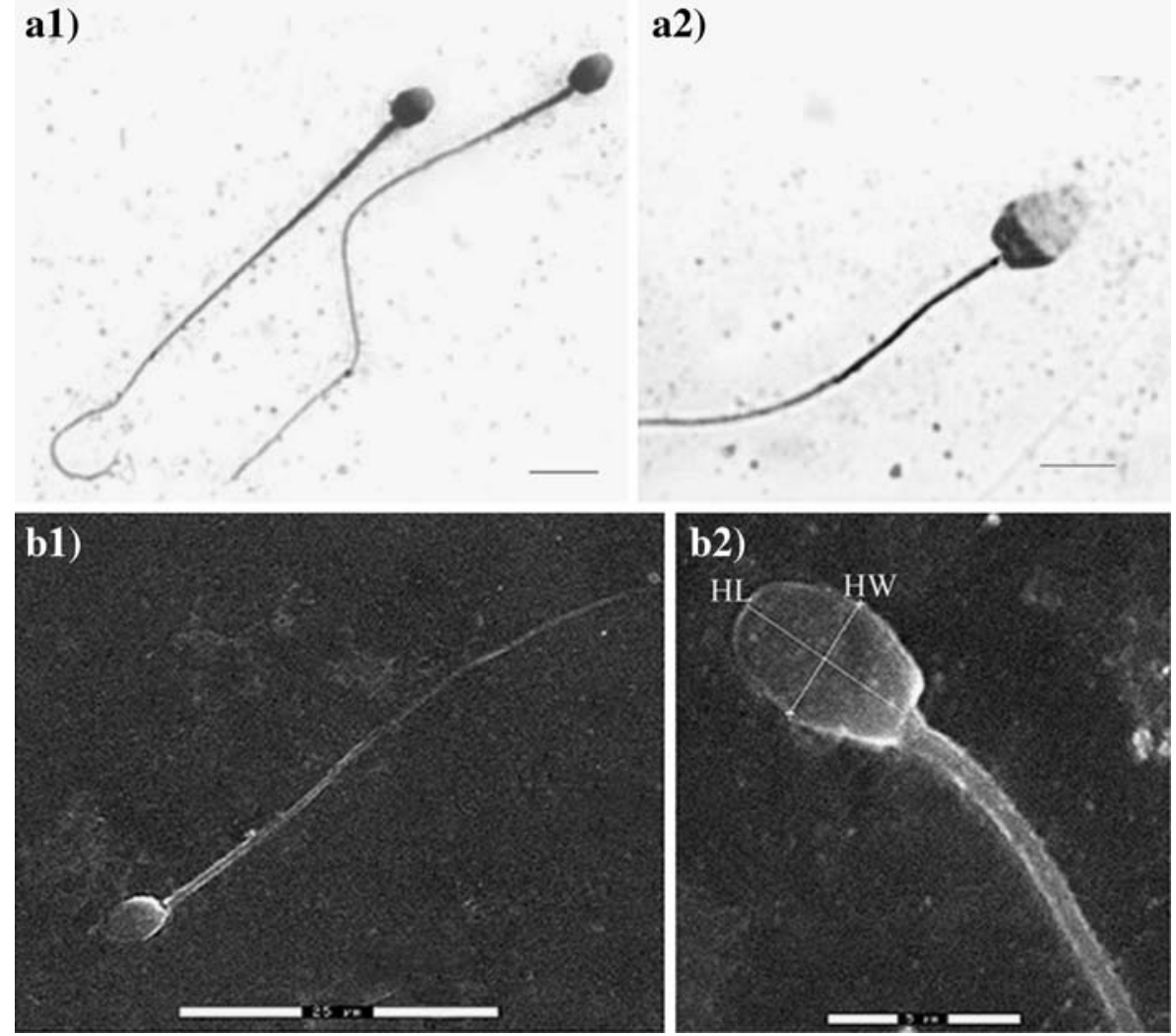

Fig. 1 Sperm cells of Saimiri boliviensis boliviensis. (a) Howell and Black (1980) stained cells via optical microscopy (bar=5 $\mu \mathrm{m})$ : (a1) $\times 400$ and (a2) $\times 1000$ magnification. (b) Environmental scanning microscopy observations and measures: (b1) $\times 1800$ and (b2) $\times 6500$ magnification: HL: head length= $4.94 \mathrm{~mm}$; HW: head width=3.11 $\mathrm{mm}$. 
box-and-whisker plot; thus the results in Table I correspond to pooled data of all 200 spermatozoa studied.

The morphometric characteristics and the aspect ratio of the head in 12 spermatozoa measured via ESEM are in Table II. There is no statistical difference in the measurements vs. the ones observed via optical microscopy ( $\chi^{2}$ test, $\left.p>0.01\right)$.

\section{Genetic Analysis}

The cytogenetic characterization of 46 individuals of Saimiri boliviensis boliviensis showed a modal number $2 \mathrm{~N}=44, \mathrm{XX} / \mathrm{XY}$ and a fundamental number $\mathrm{FN}=75$ for males and a $\mathrm{FN}=76$ for females. The G-banding pattern agrees with that previously described for Saimiri boliviensis boliviensis.

We analyzed the distribution of the heterochromatic blocks via C-banding. The $\mathrm{C}$ banded pattern shows 9 chromosomal pairs with telomeric $\mathrm{C}+$ blocks (B2-B9, and $\mathrm{B} 11)$ and 3 pairs with interstitial $\mathrm{C}+$ bands (A1, B1, B11). All chromosomal pairs show a centromeric $\mathrm{C}+$ block, corroborating the heterochromatic pattern described for Saimiri boliviensis boliviensis.

Results obtained via FISH technique employing human probes show 2 positive green signals when metaphases of female Saimiri boliviensis boliviensis were hybridized with the human $\mathrm{X}$ chromosome probe, corroborating the homology between the human X chromosome and Saimiri boliviensis boliviensis (Fig. 2). There is no signal for the Y human chromosome probe in either males or females.

We analyzed the mitochondrial COII gene in 3 squirrel monkeys, which described 3 haplotypes. Between the 2 specimens identified as Saimiri boliviensis, we identified 13 differences ( 8 transitional and 5 transversional substitutions; Table III).

\section{Discussion}

Phenotype and sperm cells morphology

The taxonomy of Ceboidea has been the object of numerous studies at the suprageneric level in the last 20 yr (Groves 2001; Horovitz 1998; Rowe 1996;

Table I Morphometric characteristics of Saimiri b. boliviensis sperm cells via optical microscopy

\begin{tabular}{llllllllll}
\hline Characteristic & $\begin{array}{l}\text { Number of } \\
\text { cells }\end{array}$ & $\begin{array}{l}\text { Mean } \\
(\mu \mathrm{m})\end{array}$ & $\begin{array}{l}\text { Median } \\
(\mu \mathrm{m})\end{array}$ & $\begin{array}{l}\text { Minimum } \\
(\mu \mathrm{m})\end{array}$ & $\begin{array}{l}\text { Maximum } \\
(\mu \mathrm{m})\end{array}$ & $\begin{array}{l}\text { Range } \\
(\mu \mathrm{m})\end{array}$ & SD & SE & Error $^{\mathrm{a}}$ \\
\hline $\begin{array}{l}\text { Total length } \\
\begin{array}{l}\text { Midpiece } \\
\text { length }\end{array}\end{array}$ & 200 & 71.39 & 72.20 & 57.95 & 84.55 & 26.60 & 4.93 & 0.35 & 0.825 \\
$\begin{array}{l}\text { Acrosome } \\
\text { length }\end{array}$ & 200 & 12.21 & 11.40 & 8.55 & 16.15 & 7.60 & 1.75 & 0.12 & 0.595 \\
$\begin{array}{l}\text { Head length } \\
\text { Head width }\end{array}$ & 200 & 3.70 & 3.80 & 2.37 & 4.75 & 2.35 & 0.34 & 0.02 & 0.495 \\
\hline
\end{tabular}

\footnotetext{
${ }^{\mathrm{a}}$ Error $=\mathrm{SE}+\mathrm{AE} ; \mathrm{AE}=$ appreciation error $=0.475$.
} 
Table II Morphometric characteristics of the sperm head of Saimiri b. boliviensis via ESEM

\begin{tabular}{llll}
\hline & Head length: (L) & Head width $(\mathrm{W})$ & Aspect ratio L/W \\
\hline Number of spermatozoa: & 12 & 12 & 12 \\
Mean & 5.06 & 3.79 & 1.34 \\
Confidence interval & $4.80-5.32$ & $3.63-3.95$ & $1.25-1.43$ \\
Median & 4.93 & 3.83 & 1.30 \\
Minimum & 4.66 & 3.11 & 1.18 \\
Maximum & 6.18 & 4.05 & 1.65 \\
Range & 1.52 & 0.94 & 0.47 \\
Standard deviation (SD) & 0.41 & 0.26 & 0.14 \\
Standard error (SE) & 0.12 & 0.07 & 0.04 \\
\hline
\end{tabular}

All measures are in $\mu \mathrm{m}$.

Ryland et al. 2000; Schneider et al. 1993, 1996). However, there is still no consensus on the classification of each genus (Rylands et al. 2000). The accurate taxonomic status of species and populations is critical for their conservation in the wild and in captivity. Incorrect assignment of species in captivity may lead to hybridization that in turn results in a reduced reproductive fitness. In addition, biomedical researchers use small platyrrhines including the common marmoset (Callithrix jacchus), owl monkey (Aotus sp.), titi monkey (Callicebus cupreus), and squirrel monkey (Saimiri sp.) because of their small body sizes, relatively early maturity, and low zoonotic risks (Tardif et al. 2006). The different species of Saimiri have a differential susceptibility to pathogens and infections (Abee 2000), thus increasing the variance and obscuring the results of biomedical research, reinforcing the importance of a correct species identification of the specimens.

Knowledge of a species' reproductive characteristics is fundamental for conservation. For both captive and wild colonies, characterization of the sperm morphology is relevant for the implementation of biotechnological techniques such

Fig. 2 FISH in a female Saimiri boliviensis boliviensis showing in green (color visible in the online version of this article) hybridization pattern with $\mathrm{X}$ human chromosome probe $(\times 1000)$. We observed no signal for the Y human chromosome probe either in the male or female squirrel monkeys.

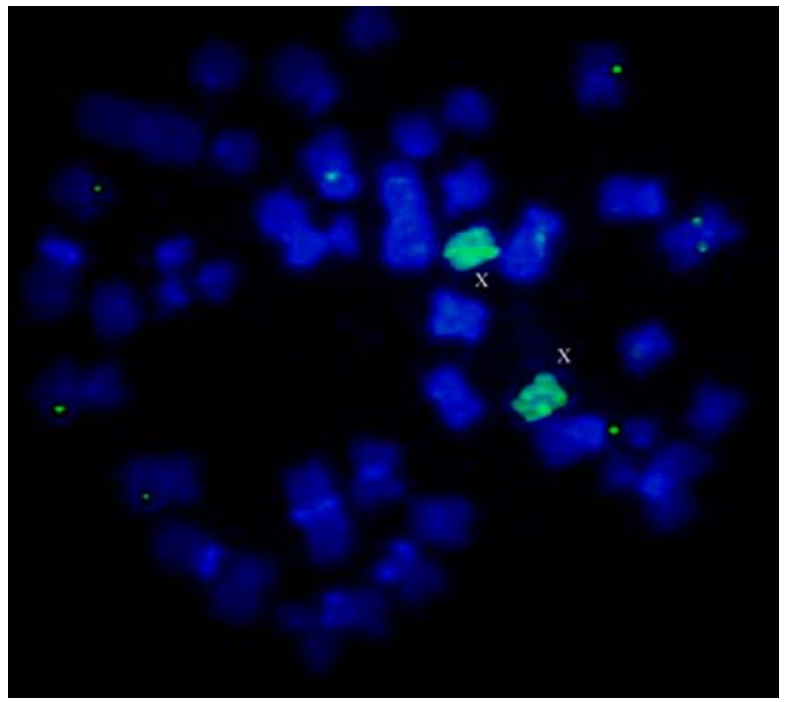


Table III Pairwise number of differences considering all nucleotide positions, and for first, second, and third position, respectively, for the specimens of Saimiri

\begin{tabular}{|c|c|c|c|c|c|c|c|c|c|c|c|c|c|c|c|}
\hline \multirow[t]{2}{*}{ Specimens (GenBank accession no.) } & \multicolumn{3}{|c|}{$\begin{array}{l}\text { All } \\
\text { positions }\end{array}$} & \multicolumn{3}{|c|}{$\begin{array}{l}\text { First } \\
\text { position }\end{array}$} & \multicolumn{3}{|c|}{$\begin{array}{l}\text { Second } \\
\text { position }\end{array}$} & \multicolumn{3}{|c|}{$\begin{array}{l}\text { Third } \\
\text { position }\end{array}$} & \multicolumn{3}{|c|}{$\begin{array}{l}\text { Amino } \\
\text { acids }\end{array}$} \\
\hline & 1 & 2 & 3 & 1 & 2 & 3 & 1 & 2 & 3 & 1 & 2 & 3 & 1 & 2 & 3 \\
\hline 1 Saimiri boliviensis (AF396460) & & 5 & 3 & & 2 & 0 & & 0 & 1 & & 3 & 2 & & & \\
\hline $2 S$. boliviensis boliviensis (AF181090) & 13 & & 8 & 4 & & 2 & 1 & & 1 & 8 & & 5 & 3 & & \\
\hline
\end{tabular}

Below the diagonal is number of differences considering all substitutions and above the diagonal (in italic) are differences due to transversions. The last 3 columns indicate pairwise number of different amino acids substiturions; below diagonal, total substitutions.

as gamete cryopreservation and assisted fertilization in zoological gardens, breeding centers, and research facilities (Wildt 1994). In mammals, the range of variation in sperm morphology is such that the dimensions and morphology of spermatozoa from different species may clearly differ; the sperm head shows the highest variation (Roldán et al. 1992). Most species have an oval or round head, with variations at the morphometric level. Exceptions are Rodentia, Pholidota, and Edentata and 2 taxa of the Primates: Lemuroidea and Lorisidae. These groups present modifications ranging from apical hooks to extensions in the base of the head (Cetica and Merani 2004; Roldán et al. 1992). Owing to high variability, researchers have used sperm morphology as a taxonomic tool in several mammalian species (Cetica et al. 1998; Gallardo et al. 2002; Meisner et al. 2005).

We describe for the first time the morphology and morphometry of the sperm cells of Saimiri boliviensis boliviensis. The sperm cells show general morphometric proportions similar to those in humans (Calamera 1992) and other mammals (Meisner et al. 2005). Comparing our data with those of other neotropical primates (González Moreno and Merani, pers. comm.; Table IV), spermatozoa of Saimiri boliviensis boliviensis contain, as a distinctive characteristic, a larger midpiece. The total length in Saimiri is larger than that of Alouatta caraya, though shorter than that of Ateles paniscus. There is no significant difference in the length or width of the sperm head. The tail insertion is central, as in the other Ceboidea. Measurements of head morphology via ESEM microscopy agree with values obtained previously via optical microscopy, but the accuracy and precision are comparatively higher. The

Table IV Sperm cells measurements $(\operatorname{mean} \pm \mathrm{SE})$ for spermatozoa of Ceboidea

\begin{tabular}{|c|c|c|c|c|c|}
\hline Variables & $\begin{array}{l}\text { Alouatta } \\
\text { caraya }^{\mathrm{a}}\end{array}$ & $\begin{array}{l}\text { Ateles } \\
\text { paniscus }^{\mathrm{a}}\end{array}$ & $\begin{array}{l}\text { Cebus apella } \\
\text { nigritus }^{\text {a }}\end{array}$ & $\begin{array}{l}\text { Cebus apella } \\
\text { paraguayanus }^{\text {a }}\end{array}$ & $\begin{array}{l}\text { Saimiri boliviensis } \\
\text { boliviensis }^{\mathrm{b}}\end{array}$ \\
\hline Total length $(\mu \mathrm{m})$ & $53.93 \pm 2.0$ & $124.61 \pm 10.3$ & $67.83 \pm 0.7$ & $67.26 \pm 2.0$ & $71.39 \pm 5.40$ \\
\hline Head length $(\mu \mathrm{m})$ & $5.0 \pm 0.4$ & $5.11 \pm 0.2$ & $5.68 \pm 0.3$ & $5.87 \pm 0.5$ & $5.71 \pm 0.81$ \\
\hline Head width $(\mu \mathrm{m})$ & $3.09 \pm 0.2$ & $3.27 \pm 0.2$ & $3.47 \pm 0.2$ & $3.72 \pm 0.4$ & $3.76 \pm 0.7$ \\
\hline $\begin{array}{l}\text { Midpiece length } \\
(\mu \mathrm{m})\end{array}$ & $3.63 \pm 0.3$ & $7.22 \pm 0.3$ & $9.29 \pm 0.4$ & $8.53 \pm 0.6$ & $12.20 \pm 2.22$ \\
\hline
\end{tabular}

\footnotetext{
${ }^{\mathrm{a}}$ Gonzales Moreno and Merani, pers comm.

b This study
} 
greatest advantage of ESEM is that one can observe the material without any previous treatment, thus ensuring that the samples are unaltered.

Inbreeding is mating of closely related individuals, and inbreeding depression is reduced fitness of the offspring of such matings vs. the offspring of randomly mated individuals. General recognition of the potential negative effect of inbreeding on fitness has made inbreeding depression a concern in small-population conservation and inbreeding avoidance is a priority in captive breeding of endangered species (Hedrick and Kalinowski 2000). Reproductive parameters, such as sperm morphology, are valuable indicators of inbreeding depression. Gomendio et al. (2000) showed that there is an increase in sperm head abnormalities and shortening of the midpiece in a colony of Gazella cuvieri with a high level of inbreeding. To our knowledge, no one has published studies of sperm morphology and inbreeding in primates. One can consider our morphometrical characterization as a first step leading to the use of these parameters as inbreeding indicators for reproductive management in Ceboidea. More studies in natural and captive populations of Saimiri are needed to evaluate the use of this parameter in colonies of Saimiri or to asses the conservation status of natural populations.

\section{Cytogenetic and Molecular Parameters}

Cytogenetic characterization allows the differentiation between Saimiri boliviensis and $S$. sciureus owing to the difference in their fundamental numbers as a result of pericentric inversions involving the B5/C1 and B10/C2 chromosomal pairs, helping with their correct taxonomic assignation (Fogle 1990; García et al. 1995; Moore et al. 1990; Mudry de Pargament 1982). Chromosomal morphology and G-banding species-specific pattern allowed an unequivocal identification of the individuals as belonging to Saimiri boliviensis boliviensis. Other important differences in the karyotype of Saimiri involve the C-banding patterns. All species have centromeric heterochromatin, but the species that possess the B5 pair, such as Saimiri boliviensis boliviensis, S. b. peruviensis, S. vanzolinii, S. oerstedii oerstedii, and S. sciurius macrodon, show a telomeric band in the q-arm of the chromosomal pair. The band is not present in the $\mathrm{C} 1$ pair of Saimiri sciureus sciureus, probably because the $\mathrm{C}+$ band was aquired by the B5 pair after the pericentric inversion that originated it (García et al. 1979).

Another heterochromatic polymorphism in the genus is the one involving chromosome B11. The pair possesses pericentromeric and interstitial heterochromatin. An addition of a $\mathrm{C}+$ band in the short arm of one of the homologues occurs, thus generating a change in its morphology, from submetacentric to metacentric. The addition might be explained by direct duplication that would increase the amount of heterochromatin. Moore et al. (1990) and García et al. (1995) previously observed the polymorphism.

FISH analysis shows no signal for the $\mathrm{Y}$ human chromosome probe, in either males or females, in agreement with previous observations in other species of Ceboidea (Consigliere et al. 1998; de Oliveira et al. 2002; Mudry et al. 2001).

As a whole, the cytogenetic tools are very useful markers for taxonomic identification at the specific and subspecific levels in Saimiri. However, we need a fine-scale resolution of the genetic structure of Saimiri populations in the wild and in 
captivity to be able to track geographic origins and define genetic structure of captive populations. For example, Lavergne et al. (2003) genotyped the colony of Saimiri of the Pasteur Institute in French Guyana via mitochondrial and microsatellite markers. They found 3 distinct mitochondrial lineages from the Saimiri boliviensis, S. sciureus and $S$. s. collinsi group and private microsatellite alleles that distinguished Bolivian specimens (S. boliviensis) from Guyanese (S. s. sciureus) and Brazilian animals ( $S$. s. collinsi). Other authors, using microsatellite markers, distinguished between Saimiri boliviensis and S. ustus, as well as to characterize the presence of hybrid individuals in the colony of the Center for Animal Breeding, Fiocruz Laboratory, Rio de Janeiro, Brasil (Carvalho, L.G., pers. comm.). One first step toward a detailed description of the genetic diversity of colonies of Saimiri in Argentina employed the mitochondrial genome. We chose the mitochondrial gene COII because it proved to be useful in some aspects of platyrrhine systematics (Ascunce et al. 2002, 2003; Ashley and Vaughn 1995; Collins and Dubach 2000; Figueiredo et al. 1998). We observed a high degree of divergence at the nucleotide level of the COII gene between the 2 specimens of Saimiri boliviensis, with values that could be associated to subspecific levels or to differentiation processes between populations. Karyological analysis of the 2 specimens showed no difference from previously described karyotype of Saimiri boliviensis boliviensis. However, they are significantly differentiated based on the mitochondrial DNA, which demonstrates the importance of the integration of different tools to obtain a proper characterization of specimens.

Morphometric and genetic characterization are useful tools in the development of plans for reproduction in captivity, contributing substantial information to the assignment of the proper taxonomic category to the focal specimens. In this context, it is important to emphasize the need for the collaborative work of biologists, veterinarians, and researchers in genetics and conservation with zoological gardens, breeding centers, and fauna protective organizations.

For species conservation and colony breeding programs, accurate taxonomic classification of each individual is critical. Karyotyping squirrel monkeys is generally sufficient to classify them into different subspecies, but other parameters are needed to determine and to maintain genetic diversity in the colony. We provide a beginning for the analysis of sperm parameters in depressed colonies and an interesting comparison of one of the mitochondrial genes.

The variables we used are from different methodologies that support the need to consider the concept of Total Evidence as indispensable in the correct taxonomic characterization of species or genera. Our results are part of our research project on the genetics of primates in captivity in Argentinean institutions (Primates Project; Martinez et al. 2004; Nieves et al. 2003, 2005, 2007). In particular, we are the first to gather information from morphological, cytogenetic, and nucleotide variation within Saimiri boliviensis. Further studies analyzing more specimens would allow a better understanding of the diversity in captive specimens of Saimiri.

Acknowledgments All research reported here complied with appropriate national and institutional guidelines for the legal acquisition and use of laboratory animals and authorized study of wild animals. The authors adhered to the Guide for Care and Use of Experimental Animals as promulgated by the Canadian Council of Animal Care. We thank the head of the institutions that made possible the genetic studies presented here, the veterinarians who collaborated in the sampling of all specimens, and the 
caretakers of the subjects. We especially thank C. Galliari (Botanical and Zoological Garden, La Plata, Argentina), G. Zunino (EBCo Breeding Center, Corrientes, Argentina); J. García (CEM Breeding Center, Chaco, Argentina), B. Carpinetti (ECAS Zoological and Breeding Center, La Plata, Argentina), M. Rivolta and M. Mas (Zoo Buenos Aires, Argentina), and G. Solís and A. Burna for their assistance in the management of the subjects, as well as M. Giordano (CITEFA), who provided valuable technical assistance with the ESEM. MDM PIP-CONICET 2450 and 5012, UBACyT X031 and X107, and ERS Sigma Xi 3040277 provided funding for this project.

\section{References}

Abee, C. R. (2000). Squirrel monkey (Saimiri spp.). Research and resources. ILAR Journal, 41, $2-9$.

Ascunce, M. S., Hasson, E. R., \& Mudry, M. D. (2002). Description of the cytochrome oxidase subunit II gene in some genera of New World monkeys (Primates, Platyrrhini). Genetica, 114, 253-267. doi:10.1023/A:1016230421820.

Ascunce, M. S., Hasson, E. R., \& Mudry, M. D. (2003). COII as a useful tool for phylogenetic studies in some genera of New World monkeys (Primates, Platyrrhini). Zoologica Scripta, 32, 397-406. doi:10.1046/j.1463-6409.2003.00123.x.

Ashley, M. V., \& Vaughn, J. L. (1995). Owl monkeys (Aotus) are highly divergent in mitochondrial cytochrome $c$ oxidase (COII) sequences. International Journal of Primatology, 16, 793-806. doi:10.1007/BF02735720.

Ayres, J. M. (1985). On a new species of squirrel monkey, genus Saimiri, from Brazilian Amazonia (Primates, Cebidae). Papeis Avulsos de Zoologia, 36, 147-164.

Boinski, S., \& Cropp, S. J. (1999). Disparate data sets resolve squirrel monkey (Saimiri) taxonomy: Implications for behavioral ecology and biomedical usage. International Journal of Primatology, 20, 237-256. doi:10.1023/A:1020522519946.

Buckton, K., \& Evans, H. (1973). Method for the Analysis of Human Chromosome Aberrations. Ginebra: WHO Publications.

Calamera, J. C. (1992). Introducción al estudio del espermatozoide. Buenos Aires, Argentina: Ediciones Hector Macchi.

Cetica, P. D., \& Merani, M. S. (2004). El espermatozoide también tiene su historia. Ciencia Hoy, 14, 10-15.

Cetica, P. D., Solari, A. J., Merani, M. S., De Rosas, J. C., \& Burgos, M. H. (1998). Evolutionary sperm morphology and morphometry in armadillos. Journal of Submicroscopic Cytology and Pathology, 30, 309-314.

Collins, A. C., \& Dubach, J. M. (2000). Biogeographic and ecological forces responsible for speciation in Ateles. International Journal of Primatology, 21, 421-444. doi:10.1023/A:1005487802312.

Consigliere, S., Stanyon, R., Koehler, U., Arnold, N., \& Wienberg, J. (1998). In-situ hybridization (FISH) maps chromosomal homologies between Alouatta belzebul (Platyrrhini, Cebidae) and other primates and reveals extensive interchromosomal rearrangements between howler monkeys genomes. American Journal of Primatology, 46, 119-133. doi:10.1002/(SICI)1098-2345(1998)46:2<119:: AID-AJP2>3.0.CO;2-Z

Costello, R. K., Dickinson, C., Rosenberger, A. L., Boinski, S., \& Szalay, F. S. (1993). Squirrel monkey (genus Saimiri) taxonomy: A multidisciplinary study of the biology of species. In W. H. Kimbel, \& L. B. Martin (Eds.), Species, Species Concepts, and Primate Evolution. New York: Plenum Press.

de Oliveira, E. H. C., Neusser, M., Figueiredo, W. B., Nagamachi, C., Pieczarka, J. C., Sbalqueiro, I. J., Wienberg, J., \& Mueller, S. (2002). The phylogeny of howler monkeys (Alouatta, Platyrrhini): Reconstruction by multicolor or cross-species chromosome painting. Chromosome Research, 10, 669-683. doi:10.1023/A:1021520529952.

Du Mond, F. V. (1967). Squirrel monkey reproduction: The "fatted" male phenomenon and seasonal spermatogenesis. Science, 158, 1067-1070. doi:10.1126/science.158.3804.1067.

Figueiredo, W. B., Carvalho-Filho, N. M., Schneider, H., \& Sampaio, I. (1998). Mitochondrial DNA sequences and the taxonomic status of Alouatta seniculus populations in northeastern Amazonia. Neotropical Primates, 6, 73-77.

Fogle, T. (1990). Role of cytogenetics for breeding management of squirrel monkey colonies. Zoo Biology, 9, 373-383. doi:10.1002/zoo.1430090505.

Gallardo, M. H., Mondaca, F. C., Ojeda, R. A., Köhler, N., \& Garrido, O. (2002). Morphological diversity in the sperms of caviomorph rodents. Mastozoología Neotropical, 9, 159-170. 
García, M., Miró, R., Ponsá, M., \& Egozcue, J. (1979). Chromosomal polymorphism and somatic segregation in Saimiri sciureus. Folia Primatologica, 31, 312-323. doi:10.1159/000155894.

García, M., Borrel, A., Mudry, M. D., Egozcue, J., \& Ponsá, M. (1995). Prometaphase karyotype and restriction-enzyme banding in squirrel monkey, Saimiri boliviensis boliviensis (Primates: Platyrrhini). Journal of Mammalogy, 76, 497-503. doi:10.2307/1382358.

Gomendio, M., Cassinello, J., \& Roldan, E. R. S. (2000). A comparative study of ejaculate traits in three endangered ungulates with different levels of inbreeding: fluctuating asymmetry as an indicator of reproductive and genetic stress. Proceedings of the Royal Society B: Biological Sciences, 267(1446), $875-882$.

Groves, C. P. (2001). Primate Taxonomy p. 350. Washington and London: Smithsonian Institution Press.

Hedrick, P. W., \& Kalinowski, S. T. (2000). Inbreeding depression in conservation biology. Annual Review of Ecology and Systematics, 31, 139-162. doi:10.1146/annurev.ecolsys.31.1.139.

Hershkovitz, P. (1984). Taxonomy of squirrel monkey genus Saimiri (Cebidae, Platyrrhini): A preliminary report with description of a hitherto unnamed form. American Journal of Primatology, 7, 155-210. doi:10.1002/ajp.1350070212.

Horovitz, I., Zardoya, R., \& Meyer, A. (1998). Platyrrhine systematics: A simultaneous analysis of molecular and morphological data. American Journal of Physical Anthropology, 106, 261-281. doi:10.1002/(SICI) 1096-8644(199807)106:3<261::AID-AJPA1>3.0.CO;2-Q

Howell, W. M., \& Black, D. A. (1980). Controlled silver staining of nucleolus organizer regions with a colloidal protective developer: A 1-step method. Experientia, 36, 1014-1015. doi:10.1007/BF01953855.

Kumar, S., Tamura, K., Jakobsen, I. B., \& Nei, M. (2001). Mega2: Molecular evolutionary genetics analysis software. Bioinformatics (Oxford, England), 17, 1244-1245. doi:10.1093/bioinformatics/ 17.12.1244.

Lavergne, A., Catzeflis, F., Lacote, S., Barnaud, A., Bordier, M., Mercereau-Puijalon, O., \& Contamin, H. (2003). Genetic analysis of the Saimiri breeding colony of the Pasteur Institute (French Guiana): Development of a molecular typing method using a combination of nuclear and mitochondrial DNA markers. Journal of Medical Primatology, 32, 330-340. doi:10.1046/j.1600-0684.2003.00038.x.

Martinez, R. A., Torres, E., Nieves, M., Szapkievich, V., Rodríguez, S., Schinini, A., Ascurra, M., \& Mudry, M. D. (2004). Genetic variability in two captive colonies of Cebus apella paraguayanus (Primates: Platyrrhini) from eastern Paraguay. Caryologia, 57, 332-336.

Meisner, A. D., Klaus, A. V., \& O'Leary, M. A. (2005). Sperm head morphology in 36 species of Artiodactylans, Perissodactylans and Cetaceans (Mammalia). Journal of Morphology, 236, 179-202. doi:10.1002/jmor.10297.

Moore, C. M., Harris, C. P., \& Abel, C. R. (1990). Distribution of chromosomal polymorphism in 3 subspecies of squirrel monkey (genus Saimiri). Cytogenetics and Cell Genetics, 53, 118-122. doi:10.1159/000132909.

Mudry de Pargament, M. D., Slavustky, I., \& Brieux de Salum, S. (1982). Estudios citogenéticos en Saimiri sciureus de Bolivia. Mendeliana, 5, 81-90.

Mudry, M. D., Slavutsky, I., \& Labal de Vinuesa, M. (1990). Chromosome comparisons among five species of Platyrrhini (Alouatta caraya, Aotus azarae, Callithrix jacchus, Cebus apella and Saimiri sciureus). Primates, 31, 415-420. doi:10.1007/BF02381112.

Mudry, M. D., Ponsa, M., Borrell, A., Gorostiaga, M., \& García, M. (1995). La citogenética en la Taxonomía de los Platirrinos con especial enfasis en cébidos de Argentina y países limítrofes. Marmosiana, 1, 79-86.

Mudry, M. D., Rahn, M. I., \& Solari, A. J. (2001). Meiosis and chromosome painting of sex chromosome systems in Ceboidea. American Journal of Primatology, 54, 65-78. doi:10.1002/ajp.1013.

Nieves, M., Steinberg, E. R., Ascunce, M. S., Oklander, L. I., \& Mudry, M. D. (2003). Proyecto Primates: Caracterización Genética de Primates en cautiverio. Zool. Latin., 5, 3-6.

Nieves, M., Ascunce, M. S., Rahn, M. I., \& Mudry, M. D. (2005). Phylogenetic relationships among some Ateles species: The use of chromosomic and molecular characters. Primates, 46, 155-164. doi:10.1007/s10329-004-0120-x.

Nieves, M., Mendez, G., Ortiz, A., Mühlmann, M., \& Mudry, M. D. (2007). Karyological diagnosis of Cebus (Primates, Platyrrhini) in captivity: Detection of hybrids and Management Program Applications. Animal Reproduction Science, in press.

Roldán, E. R. S., Gomendio, M., \& Vitullo, A. D. (1992). The evolution of eutherian spermatozoa and underlying selective forces: Female selection and sperm competition. Biological Reviews of the Cambridge Philosophical Society, 67, 551-593. doi:10.1111/j.1469-185X.1992.tb01193.x.

Rowe, N. (1996). The Pictorial Guide to the Living Primates p. 263. East Hampton, NY: Pogonias Press. 
Ruvolo, M., Disotell, T. R., Allard, M. W., Brown, W. M., \& Honeycutt, R. L. (1991). Resolution of the African hominoid trichotomy by use of a mitochondrial gene sequence. Proceedings of the National Academy of Sciences of the United States of America, 88, 1570-1574. doi:10.1073/pnas.88.4.1570.

Ryland, A. B., Schneider, H., Langguth, A., Mittermeier, R. A., Groves, C. P., \& Rodrìguez-Luna, E. (2000). An assessment of the diversity of New World Primates. Neotropical Primates, 8, 61-93.

Schneider, H., Schneider, M. P. C., Sampaio, I., Harada, M. L., Stanhope, M., Czelusniak, J., \& Goodman, M. (1993). Molecular phylogeny of the New World Monkeys (Platyrrhini, Primates). Molecular Phylogenetics and Evolution, 2, 225-242. doi:10.1006/mpev.1993.1022.

Schneider, H., Sampaio, I., Harada, M. L., Barroso, C. M. L., Schneider, M. P. C., Czelusniak, J., \& Goodman, M. (1996). Molecular phylogeny of the New World Monkeys (Platyrrhini, Primates) based on two unlinked nuclear genes: IRBP intron1 and $\varepsilon$-globin sequences. American Journal of Physical Anthropology, 100, 153-179. doi:10.1002/(SICI)1096-8644(199606)100:2<153::AID-AJPA1>3.0. $\mathrm{CO} ; 2-\mathrm{Z}$

Schreiber, A., Wang, M., \& Kaumanns, W. (1998). Captive breeding of squirrel monkeys, Saimiri sciureus and Saimiri boliviensis: The problem of hybrid groups. Zoo Biology, 17, 95-109.

Seabright, M. (1971). A rapid banding technique for human chromosomes. Lancet, ii, 971-972. doi:10.1016/S0140-6736(71)90287-X.

Steinberg, E. R., Nieves, M., \& Mudry, M. D. (2007). Meiotic characterization and sex determination system of Neotropical Primates: Bolivian squirrel monkey Saimiri boliviensis (Primates: Cebidae). American Journal of Primatology, 69, 1-6. doi:10.1002/ajp.20430.

Sumner, A. T. (1972). A simple technique for demonstrating centromeric heterochromatin. Experimental Cell Research, 75, 304-305. doi:10.1016/0014-4827(72)90558-7.

Szapkievich, V., Martinez, R., \& Mudry, M. D. (2002). New World monkeys in Argentinean zoos: Are they useful conservation iussues? Zoocriaderos, 8, 1-11.

Tardif, S., Bales, K., Williams, L., Ludlage Moeller, E., Abbott, D., Schultz-Darken, N., Mendoza, S., Mason, W., Bourgeois, S., \& Ruiz, J. (2006). Preparing New World monkeys for laboratory research. ILAR Journal, 47, 307-315.

Thorington, R. W. (1985). The taxonomy and distribution of squirrel monkeys (Saimiri). In L. A. Rosenblum, \& C. L. Coe (Eds.), Handbook of Squirrel Monkey Research (pp. 1-33). New York: Plenum Press.

Vandeberg, J. L., Willams-Blangero, S., Moore, C., Cheng, M., \& Abee, C. (1990). Genetic relationships among three squirrel monkey types: Implications for taxonomy, biomedical research, and captive breeding. American Journal of Primatology, 22, 101-111. doi:10.1002/ajp.1350220204.

Walsh, P. S., Metzger, D. A., \& Higuchi, R. (1991). Chelex ${ }^{\circledR} 100$ as a medium for simple extraction of DNA for PCR-based typing from forensic material. BioTechnique, 10, 506-513.

Wildt, D. E. (1994). Endangered Species Spermatozoa: Diversity, Research and Conservation in Function of Somatic Cells in the Testis. New York: Springer-Verlag. 